Ivan Dimich MD, Rohini Lingham MD,

Jolie Narang MD, Ian Sampson MD, Howard Shiang VMD

\title{
Esmolol prevents and suppresses arrhythmias during halothane anaesthesia in dogs
}

\begin{abstract}
The antiarrhythmic effect of esmolol, a selective beta, adrenoreceptor blocker, was evaluated in the presence of epinephrine induced arrhythmias in dogs $(n=6)$. The arrhythmogenic dose of epinephrine ( $A D E$ ) during 1.2 MAC halothane in dogs was increased from $3.23 \pm 0.25$ (mean $\pm S D$ ) to $30.90 \pm 3.56$ $\mu \mathrm{g} \cdot \mathrm{kg}^{-1} \cdot \mathrm{min}^{-1}(P<0.001)$ by the prior administration of esmolol $0.5 \mu \mathrm{g} \cdot \mathrm{kg}^{-1}$ bolus followed by an infusion at the rate of $150 \mu \mathrm{g} \cdot \mathrm{kg}^{-1} \cdot \mathrm{min}^{-1}$. Higher esmolol infusion doses of 200 $\mu g \cdot \mathrm{kg}^{-1} \cdot \mathrm{min}^{-1}$ further increased $A D E$ to $99.0 \pm 2.92$ $\mu g \cdot \mathrm{kg}^{-1} \cdot \mathrm{min}^{-1}(P<0.001)$. After discontinuation of esmolol and during continued halothane anaesthesia, ventricular tachycardia was induced by increasing the infusion rate of the $100 \mu \mathrm{g} \cdot \mathrm{ml}^{-1}$ solution of epinephrine. In all dogs ventricular tachycardia was restored to sinus rhythm by a bolus dose of esmolol $\left(I \mu \mathrm{g} \cdot \mathrm{kg}^{-1}\right)$. We conclude that esmolol pretreatment increases the ADE during halothane anaesthesia in dogs. Our data suggest that esmolol may be useful as an antiarrhythmic agent in the management of epinephrine-related ventricular arrhythmias during anaesthesia in man.
\end{abstract}

L'effet antiarythmique de l'esmonol, un agent bloqueur sélectif des récepteurs adrénergiques beta $a_{1}$ a été évalué chez des chiens (6) en présence d'arythmies induites par l'épinéphrine. La dose

\author{
Key words \\ ANAESTHETICS, VOLATILE: halothane; \\ COMPLICATIONS: arrhythmias; \\ SYMPATHETIC NERVOUS SYSTEM: pharmacology, \\ epinephrine, esmolol.
}

From the Department of Anesthesiology and Surgery, Mount Sinai School of Medicine of the City University of New York, New York, New York 10029.

This work was presented in part at the 1989 Annual Meeting of the American Society of Anesthesiologists, New Orleans, LA.

Address correspondence to: Dr. Ivan Dimich, Mount Sinai Medical Center, Department of Anesthesiology - Box 1010 , One Gustave L. Levy Place, New York, NY 10029

Accepted for publication 12th August, 1991. arythmogène d'épinéphrine ( $A D E$ ) sous 1,2 MAC d'halothane chez les chiens était augmentée de 3,23 $\pm 0,25$ (moyenne $\pm E T$ ) à $30,90 \pm 3,56 \mu \mathrm{g} \cdot \mathrm{kg}^{-1} \cdot \mathrm{min}^{-1}(P<0,001)$ suite à l'administration d'une dose d'esmonol de $0,5 \mu \mathrm{g} \cdot \mathrm{kg}^{-1}$ suivied'une perfusion à $150 \mu \mathrm{g} \cdot \mathrm{kg}^{-1} \cdot \mathrm{min}^{-1}$. Des perfusions d'esmonol plus importantes à des doses de $200 \mu \mathrm{g} \cdot \mathrm{kg}^{-1} \cdot \mathrm{min}^{-1}$ ont augmenté l'ADE $\dot{a} 99,0 \pm 2,92 \mu \mathrm{g} \cdot \mathrm{kg}^{-1} \cdot \min ^{-1}(P<0,001)$. Suite à l'arrêt de l'esmonol et sous anesthésie continue à l'halothane, une tachycardie ventriculaire était provoquée en augmentant la perfusion de la solution d'épinéphrine à $100 \mu \mathrm{g} \cdot \mathrm{ml}^{-1}$. Chez tous les chiens, la tachycardie ventriculaire faisait place à un rythme sinusal grâce à une dose de bolus de I $\mu \mathrm{g} \cdot \mathrm{kg}^{-1}$ d'esmonol. En conclusion, un pré-traitement à l'esmonol augmente l'ADE lors d'une anesthésie sous halothane chez les chiens. Nos résultats suggèrent que l'esmonol pourrait être utile en tant qu'agent antiarythmique dans le traitement des arythmies ventriculaires reliées à l'épinéphrine durant l'anesthésie chez l'homme.

The administration of epinephrine, given subcutaneously for haemostasis or parenterally for its haemodynamic effect, during halothane anaesthesia may initiate malignant ventricular arrhythmias. ${ }^{1.2}$ Although the exact mechanism of these arrhythmias is unknown, administration of beta blocking agents has been advocated for their treatment. ${ }^{1,2}$ The relatively long duration of action of the currently available intravenous beta blockers, with the potential for adverse effects such as hypotension, prolonged A-V conduction or myocardial depression, limits their use intraoperatively. ${ }^{3}$ Esmolol, an ultrashort-acting beta blocking agent, has been reported to be effective in the treatment of postoperative supraventricular tachyarrhythmias. ${ }^{4,5}$ The effect of esmolol on ventricular arrhythmias during anaesthesia has not been evaluated.

The purpose of this study was to examine the effect of esmolol on epinephrine-induced ventricular arrhythmias in dogs anaesthetized with thiopentone and halothane.

\section{Methods}

The protocol was approved by the Institutional Animal Care and Use Committee. Six mongrel dogs of either sex, weighing $20-22 \mathrm{~kg}$, were anaesthetized with thiopentone 
$10 \mathrm{mg} \cdot \mathrm{kg}^{-1}$ iv and their tracheas were intubated. Mechanical ventilation was provided by volume-controlled ventilation to maintain a $\mathrm{pH}$ of $7.33 \pm 0.5$ and $\mathrm{PaCO}_{2}$ of $35-40 \mathrm{mmHg}$. End-tidal $\mathrm{CO}_{2}$ concentration was continuously monitored. Anaesthesia was maintained with 1.2 MAC (1\%) halothane in oxygen (end-tidal concentration). This concentration was continuously monitored by an airway gas analyzer (Datex 254, Datex/Puritan Bennett Co., Wilmington, MA). Oesophageal temperature was servo-controlled between $37-39^{\circ} \mathrm{C}$ with a heating blanket and an overhead heating lamp. The femoral artery and vein were cannulated for arterial pressure monitoring, blood sampling, central venus pressure monitoring and drug and fluid administration. Lead II of the ECG was monitored continuously and recorded. Additional monitoring included arterial blood gas analysis, electrolytes and haematocrit. Maintenance fluid (5\% dextrose in $0.2 \%$ normal saline) was administered at a rate of $4 \mathrm{ml} \cdot \mathrm{kg}^{-1} \cdot \mathrm{hr}^{-1}$. To this, 50 $\mathrm{mEq} \cdot \mathrm{L}^{-1}$ sodium bicarbonate was added to prevent the metabolic acidosis noted with repeated epinephrine infusions. ${ }^{7}$ After at least $60 \mathrm{~min}$ of stabilization of halothane/oxygen anaesthesia, the following steps were undertaken.

The arrhythmogenic dose of epinephrine (ADE) was determined by using the method described by Pace et al. ${ }^{8}$ Epinephrine was diluted in $0.9 \%$ saline to a concentration of $50 \mu \mathrm{g} \cdot \mathrm{ml}^{-1}$ for lower doses and $100 \mu \mathrm{g} \cdot \mathrm{ml}^{-1}$ for higher doses. Epinephrine in standardized logarithmically spaced increasing doses $(0.67,0.82,1.00,1.22$, etc. $\mu \mathrm{g} \cdot \mathrm{kg}^{-1} \cdot \min ^{-1}$ ) was infused using a pump. When four or more premature ventricular contractions (PVC's) developed in a 15-sec period during a three-minute epinephrine infusion, this dose $\left(\mu \mathrm{g} \cdot \mathrm{kg}^{-1} \cdot \mathrm{min}^{-1}\right)$ was considered to be the ADE. If four or more PVCs did not occur within three minutes, the epinephrine infusion rate was increased after a ten-minute recovery period. During the recovery period the epinephrine infusion was discontinued. This procedure was repeated until the ADE was obtained.

After determination of the control ADE in the absence of esmolol, each dog was pretreated with esmolol. A loading dose of $0.5 \mu \mathrm{g} \cdot \mathrm{kg}^{-1}$ was given $i v$ over one minute, followed by a maintenance infusion dose of 150 $\mu \mathrm{g} \cdot \mathrm{kg}^{-1} \cdot \mathrm{min}^{-1}$. After administering the esmolol the same procedure to determine ADE was repeated, starting at the control ADE.

After determination of ADE, esmolol was discontinued for $30 \mathrm{~min}$ to allow dissipation of its effect (the half-life of the drug is approximately ten minutes). Esmolol was then restarted at a higher dose of $200 \mu \mathrm{g} \cdot \mathrm{kg}^{-1} \cdot \mathrm{min}^{-1}$ preceded by a bolus of $0.5 \mu \mathrm{g} \cdot \mathrm{kg}^{-1}$. The ADE was again determined.

After determination of ADE, esmolol was discontinued for $30 \mathrm{~min}$. Ventricular tachycardia was deliberately induced by increasing the rate of infusion of epinephrine, given in a concentration of $100 \mu \mathrm{g} \cdot \mathrm{ml}^{-1}$. Esmolol was then infused in boluses of $1 \mathrm{mg} \cdot \mathrm{kg}^{-1}$ until sinus rhythm was restored.

The epinephrine infusion was continued during the esmolol infusion as well as during the five minutes after restoration of sinus rhythm.

Data were analyzed using multivariant analyses of variance (MANOVA). Data were expressed as mean \pm SD. A statistically significant difference was assumed when $P$ was less than 0.05 .

\section{Results}

The control ADE during 1.2 MAC halothane anaesthesia was $3.23 \pm 0.25 \mu \mathrm{g} \cdot \mathrm{kg}^{-1} \cdot \mathrm{min}^{-1}$. The initial dose of esmolol increased ADE to $30.90 \pm 3.56 \mu \mathrm{g} \cdot \mathrm{kg}^{-1} \cdot \mathrm{min}^{-1}$ $(P<0.001)$. The second dose of esmolol further raised the ADE to $99.00 \pm 6.29 \mu \mathrm{g} \cdot \mathrm{kg}^{-1} \cdot \mathrm{min}^{-1}(P<0.001)$. Infusion of ephinephrine alone increased MAP compared with baseline values $(P<0.05)$. There was a further increase in MAP during infusion of esmolol and epinephrine $(P<$ 0.05 vs control and $P<0.05$ vs esmolol I infusion). Heart rate increased during the epinephrine infusion alone $(P<$ 0.05 vs baseline). Following pretreatment with esmolol there was no further increase in heart rate until the end of the second esmolol infusion period (Table).

Epinephrine-induced ventricular tachycardia was converted to sinus rhythm by one bolus of esmolol ( $1 \mathrm{mg}$. $\mathrm{kg}^{-1}$ ) in all experiments (eight trials in six dogs). Sinus rhythm was maintained for at least five minutes despite continuous epinephrine challenge.

There were no significant changes in blood gas and electrolyte measurements throughout the study. Average potassium concentrations ranged from 3.8 to $4.4 \mathrm{mEg} \cdot \mathrm{L}^{-1}$.

\section{Discussion}

The present study demonstrates that the infusion of esmolol increases ADE during halothane anaesthesia in the intact dog.

Epinephrine exerts its effect on the heart after binding to either alpha or postsynaptic beta receptors. Because most of the cardiac adrenergic receptors are of the beta subclass, it has been assumed that this is the mediating receptor mechanism for catecholamine-induced anaesthetic dysrhythmias. ${ }^{1,2}$ Hayashi et al. ${ }^{9}$ have shown in dogs that the cardiac beta adrenoreceptors play an important role in the genesis of myocardial sensitization by halothane, whereas the role of beta 2 receptors was insignificant. Maze et al. ${ }^{10}$ used selective adrenergic receptor blockade in dogs anaesthetized with halothane and exposed to epinephrine to determine whether ventricular arrhythmias were associated more with alpha or beta receptor activity. Their results supported a predominant 
TABLE Hemodynamic parameters and ADE values

\begin{tabular}{llllrc}
\hline & $\begin{array}{l}A D E \\
m g \cdot g^{-1} \cdot \min ^{-1}\end{array}$ & $\begin{array}{l}H R \\
(b p m)\end{array}$ & $\begin{array}{l}M A P \\
(m m H g)\end{array}$ & $\begin{array}{l}S B P \\
(m m H g)\end{array}$ & $\begin{array}{l}\text { DBP } \\
(m m H g)\end{array}$ \\
\hline Baseline & & $112.0 \pm 6.8$ & $114.0 \pm 5.3$ & $146 \pm 7.2$ & $93.0 \pm 4.1$ \\
Control & $3.23 \pm 0.25$ & $129.0 \pm 5.7^{\mathrm{a}}$ & $149.0 \pm 2.5^{\mathrm{a}}$ & $203.0 \pm 4.2^{\mathrm{a}}$ & $132.2 \pm 3.0^{\mathrm{a}}$ \\
Esmolol dose I & $30.90 \pm 3.56^{\mathrm{b}}$ & $129.0 \pm 4.7^{\mathrm{a}}$ & $183.4 \pm 7.4^{\mathrm{a}, \mathrm{b}}$ & $220.4 \pm 8.0^{\mathrm{a}}$ & $168.3 \pm 5.8^{\mathrm{a}, \mathrm{b}}$ \\
Esmolol dose II & $99.00 \pm 6.92^{\mathrm{b} . \mathrm{c}}$ & $159.4 \pm 9.5^{\mathrm{a} . c}$ & $190.6 \pm 9.3^{\mathrm{a} . b}$ & $258.3 \pm 7.0^{\mathrm{a} . \mathrm{b}}$ & $170.6 \pm 6.5^{\mathrm{a} . \mathrm{b}}$ \\
\hline
\end{tabular}

Control $=$ epinephrine infusion alone.

Esmolol dose $\mathrm{I}=$ Esmolol infusion $-0.5 \mathrm{mg} \cdot \mathrm{kg}^{-1}+150 \mu \mathrm{g} \cdot \mathrm{kg}^{-1} \cdot \mathrm{min}^{-1}$.

Esmolol dose II = Esmolol infusion $-0.5 \mathrm{mg} \cdot \mathrm{kg}+200 \mu \mathrm{g} \cdot \mathrm{kin}^{-1} \cdot \mathrm{min}^{-1}$.

${ }^{a} P<0.05$ vs bascline; ${ }^{b} P<0.05$ vs control; ${ }^{c} P<0.05$ vs Esmolol I.

Mean \pm SD.

role for alpha-adrenergic agonists in epinephrine-halothane-induced arrhythmias. This was in contrast to earlier observations implicating beta-adrenergic stimulation and the widespread clinical observation of a higher incidence of arrhythmias after administration of beta agonists. Zuckerman et al. ${ }^{11}$ demonstrated little arrhythmogenic activity in myocardial cells exposed to alpha-adrenergic agonists with or without halothane. Beta-adrenergic agonist exposure resulted in more arrhythmogenic activity. In order to clarify this controversy Hayashi et al. ${ }^{12}$ has shown, in dogs, that alpha ${ }_{1}$ receptors contribute to epinephrine-halothane arrhythmias at a lower level of systolic blood pressure ( $140 \mathrm{mmHg}$ or less) but may not play a role at higher ( $150 \mathrm{mmHg}$ or more) levels of systolic pressure.

Elevations in arterial blood pressure and heart rate have been regarded as important factors in the development of arrhythmias by some investigators. Reynolds et al. ${ }^{13.14}$ reported that artificial elevation of the blood pressure during an infusion of a subthreshold dose of epinephrine could induce bigeminy and the arrhythmias could be aborted by a sudden reduction of blood pressure. Arrhythmogenic stretching of the Purkinje fibres by increased afterload (blood pressure) was given as an explanation for this development. Reynolds also reported acceleration of the heart rate by approximately 40 beats $\cdot \mathrm{min}^{-1}$ prior to the onset of arrhythmias. Atrial pacing at a similarly increased rate during a subthreshold infusion of epinephrine also induced ventricular arrhythmias. They suggested that the treatment of elevated blood pressure and heart rate should be a primary goal in prevention of epinephrine-halothane arrhythmias. However, Hayashi et al..$^{15}$ demonstrated, in the intact dog preparation, that the increase in heart rate alone was not an important factor in of the aetiology epinephrine-halothane-induced arrhythmias. Furthermore, Maze et al. ${ }^{10}$ observed that while sodium nitroprusside prevented an increase in the afterload of epinephrine during halothane anaesthesia, it did not exert any antiarrhythmic activity. In the present study, esmolol did not decrease elevated blood pressure but still produced suppression of arrhythmias. This indicates that hyperten- sion is not solely responsible for the epinephrine-induced arrhythmias during halothane anaesthesia.

Despite extensive investigation, the cellular mechanisms (e.g., re-entry, automaticity or triggering) for epinephrineinduced dysrhythmia have not been established for any inhalational anaesthetic. It has been suggested that triggered activity associated with delayed after-depolarization may play a role. ${ }^{13}$ However, Freeman et al. ${ }^{16}$ demonstrated, with canine ventricular myocites, that triggered activity is not the cause of these arrhythmias. Zuckerman et al." studied the effect of halothane on arrhythmogenic responses induced by sympathomimetic agents in single rat heart cells. They concluded that a mechanism for arrhythmias does not arise at the level of single ventricular cells because halothane inhibited sympathomimetic-induced arrhythmogenic activity in their model. They indicated that the probable mechanism included alteration in impulse propagation, which might lead to a phenomenon such as re-entry. Re-entry as a likely cause has been suggested and reported by several other investigators. ${ }^{2.13}$ Esmolol, by primarily prolonging atrioventricular and intraventricular conduction, may interrupt re-entrant circus activity and terminate epinephrine-induced ventricular tachycardia.

Finally, thiopentone $\left(30 \mathrm{mg} \cdot \mathrm{kg}^{-1}\right)$ has been shown by Atlee and Malvinson ${ }^{17}$ to reduce the dose of epinephrine that produces ventricular arrhythmias in dogs anaesthetized with halothane. The effect of the lower induction dose of thiopentone $\left(10 \mathrm{mg} \cdot \mathrm{kg}^{-1}\right)$ which was administered in our study, has not been determined. However, one must presume that one dose of thiopentone could affect subsequent ADE testing with inhaled anaesthetics. ${ }^{18.19}$ Because of this, we did not start to determine the arrhythmogenic dose of epinephrine until at least $60 \mathrm{~min}$ after the induction of anaesthesia. At this time, the effect of thiopentone on the development of arrhythmias would be diminished. ${ }^{20}$ Thus, an acute increase in the ADE threshold from control in our study can be attributed to esmolol administration.

In conclusion, our data indicate that an infusion of esmolol prevents and suppresses epinephrine-induced ventricular arrhythmias during halothane anaesthesia in 
dogs. Clinical trials are needed to confirm whether esmolol has a similar antiarrhythmogenic effect during anaesthesia in man.

\section{References}

1 Katz RL, Epstein RA. The interaction of anesthetic agents and adrenergic drugs to produce cardiac arrhythmias. Anesthesiology 1968; 29: 763-84.

2 Reynolds $A K$. On the mechanism of myocardial sensitization to catecholamines by hydrocarbons anesthesia. Can J Physiol Pharmacol 1984; 62: 183-95.

3 Sing $B I V$, Jewetl $D E$. Beta adrenergic receptor blocking drugs in cardiac arrhythmias. Drugs 1974; 7: 426-61.

4 Greenspan AM, Webb S, Rae AP, Sokloh NM, Spielman $S R$. Electrophysiologic effects of esmolol: an ultra-short betablocker. Circulation 1984; 70: 1763-8.

5 Bryd R, Sung R, Marks J, Parmley $W$. Safety and efficacy of esmolol an ultrashort-acting Beta-adrenergic blocking agent for control of ventricular rate in supraventricular tachycardias. J Am Coll Card 1984; 3: 394-9.

6 Gray RJ, Bateman TN, Szer LS et al. Esmolol a new ultrashort acting beta blocking agent for rapid control of heart rate in postoperative supraventricular tachyarrhythmias. $J$ Am Coll Card 1985; 5: 1451-68.

7 Kapur PA, Flacke WE. Epinephrine induced arrhythmias and cardiovascular function after verapamil during halothane anesthesia in the dog. Anesthesiology 1981; 55: 218-25.

8 Pace NG, Ohmara A, Wong KC. Epinephrine induced arrhythmias; effect on exogenous proslaglandins and prostaglandin synthesis inhibition during halothane- $\mathrm{O}_{2}$ anesthesia in the dog. Anestn Analg 1979; 58: 401-4.

9 Hayashi Y, Sumikawa K, Fukuitsu K. Contribution of action of cardiac Bl and B2 adrenoreceptors on induction arrhythmias during halothane anesthesia in dogs. Anesthesiology 1989; 72: A517.

10 Maze $M$, Smith $C M$. Identification of receptor mechanisms mediating epinephrine induced arthythmias during halothane anesthesia in dogs. Anesthesiology 1983; 59: 322-6.

11 Zuckerman $R$, Wheeler $D$. The effect of halothane on arrhythmogenic responses induced by sympathomimetic agents in single rat heart cells. Anesth Analg 1990; 70: S450.

12 Hayashi Y, Sumikawa K, Tashiro C, Yoshiya L. Synergistic interaction of alpha- $I$ and beta adrenoreceptor agonists on induction arrhythmias during halothane anesthesia in dogs. Anesthesiology 1988; 68: 902-7.

13 Reynolds AK. Cardiac arrhythmias in sensitized heart. Primary mechanism involved. Res Commun Chem Pathol Pharmacol 1983; 40: 3-14.
14 Reynolds $A K$, Chir JF, Parguet $A F$. Halothane and methoxyflurane. A comparison of their effects on cardiac pacemaker fibers. Anesthesiology 1981; 55: 218-25.

15 Hayashi Y, Simkawa K, Yamatodian A et al. Myocardial epinephrine sensitization with subanesthetic concentration of halothane in dogs. Anesthesiology 1991; 74: 134-7.

16 Freeman $L$, Quan $L$. Effect of halothane on delayed after depolarization and calcium transient in dog ventricular myocytes exposed to isoproterenol. Anesthesiology 1991; 74: 146-54.

17 Atlee JL, Malkinson RL. Thiopental potentiate of epinephrine sensitization with halothane. Anesthesiology 1980; 53: 135-9.

18 Atlee JL, Roberts $F L$. Thiopental and epinephrine-induced dysrhythmias in dogs anesthetized with enflurane or isoflurane. Anesth Analg 1986; 65: 437-43.

19 Hayashi Y, Sumikawa K, Yamarodani et al. Myocardial sensitization by thiopental to arrhythmogenic action of epinephrine in dogs. Anesthesiology 1989; 71: 929-35.

20 Bischoff $K B$, Dedrick $R L$. Thiopental pharmacokinetics. J Pharm Sci 1968; 57: 1346-51. 